\title{
PENGALIHAN PIUTANG DENGAN SKEMA CESSIE DALAM HUKUM PERBANKAN SYARIAH MAUPUN KONVENSIONAL
}

\author{
Ade Darmawan Basri \\ Universitas Islam Negeri Alauddin Makassar \\ ade.darmawan@uin-alauddin.ac.id
}

\begin{abstract}
This study is entitled "Transfer of Receivables with the Cessie Scheme in Sharia and Conventional Banking Laws and the Submission of Cessie Cases in Courts". The main problem or the core that will be examined is how the terms of the cessie and a description of the cessie then how is the form of the settlement of the case transfer of cessie receivables in court. This research is an empirical juridical legal research that describes the results of research on the applicable law in the community that is legal research conducted by collecting data with the facts that occur and field studies in general or should, with the method of the statue approach legislation. Based on the results of research and analysis conducted, a conclusion can be drawn that the application of the transfer of receivables with the cessie scheme is a way of transferring receivables or handing over receivables on behalf as stated in Article 613 of the Civil Code, with the case settlement process through civil lawsuit to cessus can also be said to be a creditor and in fact can also be submitted an application or can be called a voluntary suit as long as there is no dispute from the old debtor or the creditor, can be resolved in the District Court or the Religious Court depending on the banking party intended to be sued or filed an application in other words whether it is Islamic Banking or Conventional Banking.
\end{abstract}

Keywords: Cessie, Civil Lawsuit, Petition, Transfer of Receivables.

\begin{abstract}
Abstrak
Penelitian ini berjudul "Pengalihan Piutang Dengan Skema Cessie Dalam Hukum Perbankan Syariah Maupun Konvensional Dan Pengajuan Perkara Cessie Di Pengadilan". Permasalahan pokok atau inti yang hendak dikaji adalah bagaimanakan syarat dari cessie serta gambaran terhadap cessie kemudian bagaimanakah bentuk penyelesaian perkara pengalihan piutang cessie di pengadilan. Penelitian ini merupakan penelitian hukum yuridis empiris atau penelitian hukum yang menggambarkan hasil penelitian tentang hukum yang berlaku dimasyarakat yaitu penelitian hukum yang dilakukan dengan cara mengumpulkan data-data dengan kenyataan yang terjadi maupun studi lapangan pada umumnya atau yang seharusnya, dengan metode pendekatan statue approach atau pendekatan perundang-undangan. Berdasarkan hasil penelitian dan analisa yang dilakukan, dapat ditarik sebuah kesimpulan bahwa penerapan pengalihan
\end{abstract}


piutang dengan skema cessie itu sebuah cara pengalihan piutang atau penyerahan piutang atas nama sebagaimana yang tertera pada Pasal 613 KUHPerdata (Kitab Undang-Undang Hukum Perdata), dengan proses penyelesaian perkara melalui gugatan contentiosa atau gugatan perdata ke cessus dapat juga dikatakan kreditur dan juga dalam kenyataannya dapat pula diajukan permohonan atau dapat disebut gugatan voluntair selama tidak ada sengketa dari pihak debitur lama maupun dari pihak kreditur, dapat diselesaiakan di Pengadilan Negeri maupun Pengadilan Agama tergantung pada pihak perbankan yang dituju untuk diguagat ataupun diajukan permohonan dengan kata lain apakah itu Perbankan Syariah atau Perbankan Konvensional.

\section{Kata Kunci: Cessie, Gugatan Perdata, Pengalihan Piutang, Permohonan.}

\section{PENDAHULUAN}

Manusia sebagai makhluk sosial tidak dapat hidup sendiri dan akan selalu membutuhkan manusia lain untuk memenuhi kebutuhannya sehari-hari, baik itu kebutuhan ekonomi secara finansial, kebutuhan pangan secara lahiria, dan kebutuhan lainnya. Kebutuhan lainnya pun tidak luput dari proses transaksi jual beli, pinjam meminjam, sewa menyewa, hingga urusan utang piutang serta usahausaha lainnya baik untuk kemaslahatan umum maupun untuk kepentingan sendiri. Namun pada kenyataannya seringkali kita temukan atau dapatkan permasalahan mengenai kecurangan-kecurangn pada permasalahan muamalah. Perbankan syariah adalah salah satu alternatif sebuah pilihan di tengah kebutuhan masyarakat dalam layanan perbankan.

Suatu sistem perbankan yang pelaksanaannya berdasarkan hukum Islam/syariah sering disebut Mashrafiyah al-Islmiyah. Dimana pada sistem ini terdapat larangan dalam agama Islam untuk meminjamkan atau memungut pinjaman dengan memberikan bunga pinjaman/riba, serta larangan untuk berinvestasi pada usaha-usaha yang terlarang (haram).

Perbankan sebagai financial intermediary institution memegang peran penting dalam proses pembangunan ekonomi nasional. Hal ini dapat dilihat dari berbagai kegiatan usaha utama bank, seperti menarik dana lagsung dari masyarakat dalam bentuk kredit dan/atau bentuk lainnya. Sudah menjadi kewajiban bank untuk menerapkan prinsip kehati-hatian selain itu perbankan juga harus menjaga kesehatan bank agar tetap terus terjaga untuk kepentingan masyarakat umumnya serta pada khususnya untuk para nasabah.

Dengan diberikannya fasilitas kredit yang diterima oleh debitur pada umumnya dimintakan untuk menyerahkan jaminan kepada pihak Bank guna menjamin pelunasan hutangnya kepada Bank. Pasal 1131 KUHPerdata menyatakan bahwa setiap keberadaan seseorang, baik berupa benda bergerak maupun tidak bergerak, baik yang telah ada maupun yang akan ada di kemudian hari, merupakan 
tanggungan untuk segala perikatan perseorangan dan merupakan jaminan hutanghutangnya. ${ }^{1}$

Perkembangan yang terjadi pada sektor ekonomi dan sosial khususnya, baik dalam skala nasional maupun internasional, baik itu secara langsung maupun itu secara tidak langsung dapatlah mempengaruhi likuiditas serta beberapa kebijakan tenytang penyaluran kredit pada Bank selaku kreditur tentunya. Bank selaku kreditur suatu saat akan berkeinginan untuk mengundurkan diri dari partisipasinya. Pengunduran diri kreditur tentu saja akan dapat mempengaruhi kegiatan usaha yang dilakukan oleh debitur apabila dana yang dipergunakan melakukan sebuah kegitan usaha berasal dari beberapa fasilitas kredit Bank. Agar pendanaan dalam kegiatan tidak terhenti maka dikenallah lembaga pengalihan piutang yang dilakukan dengan cara skema cessie. Suatu tagihan dikarenakan debitur sehingga menyebabkan hutang kepada kreditur. Berdasarkan dari ketentuan Pasal 1338 KUHPerdata dimana dikatakan bahwa setiap perjanjian yang dibuat secara setiap perjanjian yang dibuat secara sah dan berlaku sebagai perundangan untuk para pihak yang telah membuatnya.

Pemberian kredit oleh bank dituangkan dalam sebuah perjanjian berisi kesepakatan antara bank dengan kreditur dengan nasabah selaku penerima kredit yang biasa disebut dengan debitur. Dasarnya pemberian kredit oleh bank kepada nasabah selaku debitur yaitu adanya kepercayaan yang timbul sebab telah terpenuhinya segala ketentuan dan persyaratan untuk memperoleh kredit oleh debitur yaitu lebih jelasnya tujuannya untuk kredit, adanya benda yang dijaminkan atau benda jaminan atau agunan dan lainnya. ${ }^{2}$

Cessie adalah suatu cara pengalihan piutang atas nama yang diatur dalam Pasal 613 KUHPerdata. Pengalihan ini terjadi atas dasar suatu peristiwa perdata, seperti perjanjian jual-beli antara kreditur lama dengan calon kreditur baru. Dalam cessie itu sendiri utang piutang yang lama tidak hapus, hanya saja beralih kepada pihak ketiga sebagai kreditur baru. ${ }^{3}$ Kreditur senantiasa yang diinginkan adalah agar bagaimana jaminan yang telah diberikan kepadanya dapat menjamin pelunasan utang dari debitur. Dimana jaminan merupakan bentuk kemampuan debitur untuk memenuhi atau dengan kata lain melunasi utangnya kepada kreditur, yang dilakukan dengan cara menahan benda tertentu yang ada nilai ekonomisnya sebagai bentuk tanggungan atas pinjaman atau utang yang diterima debitur atau

${ }^{1}$ Satrio, Cessie, Subrogatie, Novatie, Kompensatie dan Percampuran Hutang, cet. 2, (Bandung: Alumni, 1999). h. 2.

2 Hermansyah, Hukum Perbankan Nasional Indonesia, Edisi 2, Cet.8, (Jakarta: Prenada Media Group, 2014). h. 58.

${ }^{3}$ Suharnoko, Doktrin Subrogasi, Novasi, dan Cessie, edisi pertama, (Jakarta: Kencana Prenada Media Group, 2016). h.101. 
dengan kata lain bentuk jaminan terhadap krediturnya. ${ }^{4}$ Jaminan dapat berupa atau berbentuk benda bergerak maupun tidak bergerak. Suatu benda dapat digolongkan dalam bentuk benda tidak bergerak yaitu karena sifatnya, tujuan pemakaiannya, maupun yang ditentukan oleh undang-undang. ${ }^{5}$ Kemudian juga yang dapat digologkan sebagai benda yang tidak bergerak yaitu segala sesuatu melekat juga diatasnya dalam hal ini obyek jaminan yang telah dijaminkan.

Jaminan yang berupa hak atas tanah yang telah dibebankan Hak Tanggungan dibuatkan dalam suatu perjanjian secara tersendiri yang merupakan tambahan dari sebuah perjanjian atau accessoir dari perjanjian kredit yang telah dibuat sebelumnya. Sifatnya yang accesoir disini mempunyai arti dimana hak ini tidak berdiri sendiri melainkan diaman keberadaan atau terhapusnya tergantung dari pada perjanjian pokoknya yaitu perjanjian kredit, namun perjanjian accesoir akan selalu mengikut pada perjanjian pokoknya. Jadi apabila seorang kreditur yang menglihkan piutangnya kepada kreditur baru mahak Hak Tanggungan akan mengikutinya. Cessie juga dapat dikenal sebagi pengalihan piutang atau hak tagih dari kreditur lama kepada kreditur baru. Dengan adanya pengalihan piutang secara skema cessie, maka pihak ketiga menjadi kreditur baru, dan semua hak dan kewajiban dari kreditur lama akan beralih kepadanya selaku kreditur baru. Apabila yang menjadi jaminan untuk pelunasan hutang debitur adalh dengan memakai Hak Tanggungan, sesuai dengan Pasal 16 ayat 1 UUHT, piutang yang dijamin dengan Hak Tanggungan beralih karena cessie, subrogasi, pewarisan, atau sebab lainnya, maka Hak Tanggungan teresebut ikut beralih karena hukum kepada kreditur baru. ${ }^{6}$

Berdasarkan uraian yang telah diuraikan bahwa cessie adalah sebuah cara untuk mengalihakan piutang atas nama tanpa mengakibatkan perjanjian kredit atau pinjaman atau pinjam meminjam uang yang akan berakibat munculnya piutang menjadi terhapus. Penelitian ini berfokus pada Analisis yuridis konstruksi hukum terhadap kasus atau permasalahan pengalihan piutang dengan skema cessie yang dipandang dari segi praktik baik di pengadilan agama maupun di pengadilan negeri, dalam bentuk gugatan maupun permohonan.

\section{METODE PENELITIAN}

Penelitian ini menggunakan metode kualitatif, lebih bersifat deskriptif dengan jenis penelitian kepustakaan (library research). Penelitian ini dilakukan

\footnotetext{
${ }^{4}$ Rachmadi Usman, Hukum Jaminan Keperdataan, (Jakarta: Sinar Grafika, 2009). h. 66.

${ }^{5}$ Subekti, Pokok-Pokok Hukum Perdata, Cet. 31, (Jakarta: Intermasa, 2003). h. 61.

${ }^{6}$ Indonesia, Undang-Undang Hak Tanggungan, Psl. 16 ayat 1 
berdasarkan studi pustaka dengan berbagai referensi jurnal dan buku serta beberapa artikel terbaik dan terupdate.

Adapun jenis dan sumber data yang digunakan dalam penelitian ini anatara lain berupa data primer dan sekunder. Data primer, yaitu data yang diperoleh dari hasil analisis terhadap hasil-hasil ungkapan terkait penelitian oleh beberapa pakar atau peneliti yang memiliki keterkaitan dengan penelitian ini. Data sekundar, yaitu data yang sudah tersedia sehingga peneliti mencari dan mengumpulkan penulisan dari (data yang diperoleh dari buku-buku, internet, jurnal dan perundang-undangan yang terkait) kesemuanya yang berkaitan hubungannya dengan cessie.

Teknik pengumpulan data yang diperlukan, yaitu Penelitian Pustaka (library research), Penelitian Pendekatan Perundang-Undangan (Statue Approach). Penelitian dilaksanakan dengan mengumpulkan data dan landasan teoritis dengan mempelajari buku, karya ilmiah, hasil penelitian terdahulu, jurnal-jurnal terkait, artikel-artikel yang terkait serta sumber-sumber yang terkait dengan penelitian sesuai dengan penelitian yang diteliti. Pendekatan Perundang-Undangan (Statue Approach) dilakukan dengan menelaah semua peraturan perundang-undangan dan regulasi yang terkait dengan isu hukum yang sedang ditangani. ${ }^{7}$

Teknik Analisis Data, Setelah semua data telah diperoleh berhasil dikumpulkan selama proses penelitian baik data primer dan data sekunder dianalisis secara kualitatif kemudian disajikan secara deskriptif yaitu menjelaskan, menguraikan, menggambarakan permasalahan yang berkaitan dengan pengalihan piutang dengan skema cessie dalam perbankan syariah maupun konvensional dan pengajuan ke pengadilan dalam bentuk sebuah penelitian jurnal.

\section{PEMBAHASAN}

\section{A. Pengertian Mengenai Cessie}

Dalam literatur hukum terdapat banyak pengertian tentang pengalihan piutang dengan skema cessie yang telah dirumuskan oleh para pakar baik dalam sebuah jurnal maupun penelitian lainnya maupun penelitian di lapangan. Rumusan dari pengalihan piutang atau cessie ini oleh para pakar hukum jika kita cermati pada dasarnya tidak lepas dari ketentuan yang tercantum pada Kitab Undang-Undang Hukum Perdata yang berasal dari produk pemerintah Hindia Belanda yang telah diundangkan pada tahun 1848 yang masih berlaku dan tidak bertentangan dengan UUD 1945, Pancasila, Peraturan Perundang-Undangan, serta dibutuhkan ${ }^{8}$. Kemudian juga yang berhubungan dengan praktik peradilan di Indonesia.

7 Peter Mahmud Marzuki, Penulisan Hukum, (Jakarta: Kencana Prenada Media Group, 2014). hlm. 33.

${ }^{8}$ Salim H.S, Pengantar Hukum Perdata Tertulis (BW), (Jakarta: Sinar Grafika, 2005) 
Cessie adalah sebuah cara pengalihan piutang atau penyerahan piutang atas nama sebagaimana yang tertera pada Pasal 613 KUHPerdata (Kitab UndangUndang Hukum Perdata $)^{9}$. Namun kemudian, kata Cessie tidak terdapat di dalam undang-undang yang telah berlaku di Indonesia. Pasal 613 KUHPerdata atau BW berada dalam bagian Kedua Buku II BW di bawah judul "Tentang Cara Memperoleh Hak Milik", maka dapat disimpulkan bahwasanya yang dimaksudkan dengan penyerahan dalam Pasal 613 KUHPerdata atau BW yaitu penyerahan kedalam kepemilikan dari orang yang menerima penyerahan itu. Dengan demikian bahwa problemnya ada pada penyerahan tagihan atas nama dan benda-benda yang tak bertubuh lainnya. Pasal 613 KUHPerdata menyebutkan bahwa:

"Penyerahan akan piutang-piutang atas nama dan kebendaan tidak bertubuh lainnya, dilakukan dengan jalan membuat sebuah akta otentik atau di bawah tangan, dengan mana hak-hak atas kebendaan itu dilimpahkan kepada orang lain. Penyerahan yang demikian bagi yang berhutang tidak ada akibatnya, melainkan setelah penyerahan itu diberitahukan kepadanya atau secara tertulis disetujui dan diakuinya. Penyerahan tiap-tiap piutang karena surat bahwa dilakukan dengan penyerahan surat; penyerahan tiap-tiap piutang karena surat ditunjuk dilakukan dengan penyerahan surat disertai dengan endorsemen".

Unsur-unsur yang dapat disimpulkan berdasarkan Pasal 613 KUHPerdata yang berkaitan dengan Cessie, yaitu:

1. Dibuatkan akta otentik atau akta di bawah tangan;

2. Hak-hak yang melekat pada piutang atas nama yang berpindah atau dialihkan pada pihak penerima pengalihan;

3. Cessie berlaku akibat hukum terhadap debitur apabila telah diberitahukan kepadanya atau di beritahukan secara tertulis dan telah diakuinya.

Dalam Pasal 584 BW diatur cara memperoleh hak milik, yaitu: "Hak milik atas suatu kebendaan tak dapat diperoleh dengan cara lain, melainkan dengan pemilikan, karena perlekatan, karena kedaluarsa, karena pewarisan, baik menurut undang-undang maupun menurut surat wasiat, dan karena penunjukan tau penyerahan berdasarkan atas suatu peristiwa perdata untuk memindahkan hak milik, dilakukan oleh seseorang yang berhak berbuat bebas terhadap kebendaan itu".

Dari sekian banyak cara untuk memperoleh hak kepemilikan yang disebut dalam Pasal $584 \mathrm{BW}$, yang sehubungan dengan pembicara tentang cessie

9 Soeharnoko dan Endah Hartati, Doktrin Subrogasi, Novasi dan Cessie, (Jakarta: Kencana, 2008). h. 101. 
sanagtlah relevan untuk di perhatikan yakni cara untuk memperoleh hak milik. Adapun unsur-unsur yang dapat diambil dari pPasal 584 BW ini yaitu:

1. Adanya penyertaan;

2. Berdasarkan suatu peristiwa perdata atau adanya peristiwa keperdataan;

3. Penyerahannya untuk memindahkan hak milik;

4. Dilakukan oleh orang yang berhak untuk berbuat sebebasnya terhadap benda itu.

Dalam skema cessie pihak yang menyerahkan atau mengalihkan piutangnya itu disebut sebagai Cedent, dan pihak yang menerima penyerahan atau pengalihan piutang disebut Cessionaris, kemudian debitur dari tagihan yang dialihkan disebut Cessus. ${ }^{10}$ Penyerahan utang piutang kebendaan tak bertubuh dan atas nama dilakukan dengan dibuatkan atau dilakukan pendaftaran atau pembuatan akta otentik atau di bawah tangan dengan hak-hak atas kebendaan dilimpahkan kepada orang lain.

Dengan adanya penyerahan piutang dengan skema cessie, maka pihak ketiga akan menjadi kreditur baru menggantikan kreditur lama dan diikuti dengan beralihnya seluruh hak dan kewajiban kreditur lama terhadap debitur kepada pihak ketiga selaku kreditur yang baru. Pengalihan tersebut dikarenakan adanya pengalihan piutang secara cessie yang tidak mengakibatkan berakhirnya perikatan yang telah ada dan dibuat antara debitur dan kreditur. Hubungan hukum kreditur dan debitur berdasarkan perjanjian kredit yang telah dibuat sebelumnya, sehingga tidak menimbulkan hubungan atau akibat hukum yang baru karena tdak menggantikan hubungan hukum yang sebelumnya atau hubungan hukum yang lama.

Dengan adanya skema cessie, maka akibat hukum yang terpentingan yaitu:

a. Piutang beralih dari cedent ke cessionaris;

b. Setelah cessie terjadi atau berlaku, kedudukan dari cessionaris akan menggantikan kedudukan cedent, yang berarti bahwasanya segala hak yang telah dimiliki oleh cedent terhadap cessus dapat digunakan oleh cessionaris sepenuhnya. ${ }^{11}$

Kemudian kita beralih pada konsekuensi dari skema itu sendiri bahwasanya pengalihan piutang dalam cessie memberikan hak untuk penerima cessie dalam hal ini adalah cessionaris sebagai kreditur yang baru bagi debitur atau cessus sehingga hubungan berikutnya yaitu antara kreditur yang baru dengan segala

10 Herlien Budiono, Ajaran Umum Hukum Perjanjian dan Penerapan di Bidang Kenotariatan, (Bandung: Citra Aditya, 2010). h. 185.

11 Rahman Setiawan dan J. Satrio, Penjelasan Hukum tentang Cessie, (Jakarta: PT. Gramedia, 2010) h. 56. 
akibat hukum dari peralihan piutang itu memberikan hak untuk kreditur yang baru untuk mengajukan gugatan kepada debitur ${ }^{12}$, sebagaimana terdapat banyaknya gugatan yang diajukan oleh cessionaris kepada cessus diberbagai kota di seluruh Indonesia khusunya di sini dalam bidang perbankan karena kaitannya erat dengan pihak perbankan, karena sejauh pengetahuan peneliti bahwasanya pengalihan piutang secara cessie ini tidak disebarluaskan atau dapat dikatakan hanya pihak bank yang mengetahui bahwa pengalihan piutang cessie ini dapan diajukan gugatan. Jadi, pihak kreditur yang telah menarik segala hal yang telah dijaminkan oleh kreditur lama dengan kata lain bias karena kredit macet atau jatuh tempo pembayaran maka kreditur yang mengambil jaminan serta benda yang tak bertubuh yang telah dimiliki oleh debitur lama yang masa pembayarannya jatuh tempo tersebut diambil oleh pihak kreditur yang kemudian di berikan kepada debitur baru yang ingin membelinya secara cessie.

Cessie dapat dilakukan melauli akta otentik atau akta bawah tangan. Syarat utama keabsahan dari pengalihan piutang secara cessie adalah pemberitahuan cessie tersebut kepada pihak terutang untuk disetujui dan diakuinya. Pihak terutang di sini adalah pihak terhadap mana si berpiutang memiliki tagihan.

\section{B. Permasalahan Yang Timbul Dalam Cessie}

Benda tak bertubuh baik itu berupa tagihan atas nama, maupun benda yang tidak bertubuh lainya yang artinya yang tidak ada wujudnya, makasangat patut untuk dipertanyakan sebab seseorang mau menyerahkan suatu benda yang tidak ada wujudnya. Tindakan penyerahan tidak pernah berdiri sendiri, tidakan demikian selalu merupakan sebuah konsekuensi yang harus diterima lebih lanjut dari suatu peristiwa hukum, yang mewajibkan seseorang untuk menyerahkan sesuatu atau dengan kata lain sesuatu itu beruba benda, berdasarkan hubungan dalam Pasal 613 BW yang berupa tagihan atas nama atau suatu benda tidak bertubuh lainnya.

Hubungan hukum yang mewajibkan adanya penyerahan disebut hubungan hukum obligatoir, yang dapat timbul dari perjanjian ataupun undang-undang. Peristiwa yang menjadi dasar dari penyerahan di sebut peristiwa perdata atau rechtstitel yaitu peristiwa yang menimbulkan sebuah perikatan diantara kedua belah pihak secara keperdataan, yang mana satu pihak sebagai kreditur dan pihak lain berkedudukan sebagai debitur. Orang menyebut peristiwa perdata atau rechtstitel sebagai hubungan yang menjadi dasar cessie. ${ }^{13}$

Pengalihan piutang cessie erat kaitannya dengan perjanjian kredit bank, dimana bank mengatur berbagai macam klausul di dalamnya, yang mana jika dilihat dari

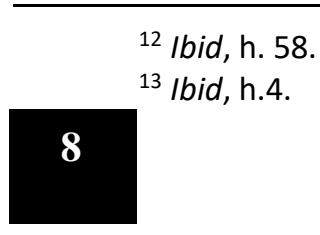


sudut pandang hukum perikatan maka ketentuan dari perjanjian kredit termasuk dalam perjanjian sepihak. Sepihak karena perjanjian ini tidak terdapat adanya tawar menawar antara debitur dan bank, bank di sini juga bias berlaku kedudukannya sebagai kreditur. Secara umum isi perjanjian kredit berisi pihak pemberi kredit, tujuan pemberian kredit, besarnya biaya proyek, besarnya kredit yang diberi oleh pihak bank, tingkatan bunga kredit, serta dengan biaya-biaya lainnya, jadwal pengembalian, jangka waktu pengembalian, jadwal pembayaran, jaminan atas kredit, syarat yang harus dipenuhi sebelum dicairkan, kewajiban nasabah selama kredit belum lunas, serta hak-hak yang dimiliki bank selama kredit tertentu belum dilunasi atau belum lunas. ${ }^{14}$

Bank yang mengatur semua perjanjian kredit dan debitur hanya menyetujui dan sepakat untuk memberikan hak sepenuhnya kepada bank untuk menyerahkan piutang atau cessie dan tagihan bank terhadap debitur beserta semua janji accesoirnya, juga termasuk ha katas jaminan kredit kepada pihak lain yang telah ditetapkan oleh bank sendiri setiap saat jika diperlukan oleh bank. Jadi, adanya pengalihan piutang secara skema cessie karena bank yang telah diatur dalam perjanjian kredit yang telah dibuat oleh bank dan hal lain yang sifatnya mengikat debitur sebagai pihak yang memohonkan kredit dan menandatangani perjanjian kredit.

Adapun pokok-pokok yang dapat diketahui tentang cessie, yaitu: ${ }^{15}$

1. Cessie dalam Praktek Perbankan

Digunakan sebagai salah satu lembaga jaminan sebagai anggunan tambahan, dimana cessie disini sebagai piutang atas nama yang dikonstruksikan secara hukum sebagai jaminan hak gadai semu (oneigelijcke pandrecht), posisinya sama dengan penyerahan dengan constitutum possessorium, tetapi pada cessie tagihan sebagai jaminan tidak ada contitutum possessorium. Tujuannya juga berbeda dan mempunyai dua sisi. cessie sebagai cara penyerahan tagihan atas nama mempunyai droit de suite tanpa pemberitahuan, dalam arti hak milik atas tagihan yang di cedeer sudah beralih pada cessionaris, walaupun belum ada pemberitahuan kepada cessus. Dikarenakan dalam praktik pada umumnya orang yang tidak menghendaki diketahui bahwa ia mempunyai utang, dan karenanya atas dasar itu dan disamping itu juga atas dasar adanya ongkos-ongkos yang perlu dikeluarkan, biasanya tidak dilaksanakan pemberitahuan penjaminan tagihan kepada cessus, sampai muncul adanya kepailitan atau wanprestasi

\footnotetext{
${ }^{14}$ Juli Irmayanto dkk, Bank dan Lembaga Keuangan, (Jakarta: Universitas Trisakti, 2004). h. 83.

${ }^{15}$ Rachmad dan J. Satrio, Op.Cit. h. 45. 
(ingkar janji) pada debitur atau cedent. Betekening atau pemberitahuan kepada yang berutang dapat dilakukan kemudian bila telah dianggap perlu oleh bank sebagai kreditur dan cessionaris.

2. Penggunaan cessie sebagai jaminan

Disini tidak bertentangan dengan asas-asas Hukum Jaminan, yang mana ternyata cessie piutang atas nama memiliki ciri-ciri sebagai gadai piutang atas nama, tetapi dikarenakan piutang atas nama telah memiliki nilai atau harga, maka dengan demikian penerima cessie atau cessionaris dapat langsung menguasai piutang atas nama tersebut (tidak bertentangan dengan Pasal 1154 BW) dan karenanya kreditur atau cessionaris tidak perlu melakukan penjualan piutang atas nama di muka umum atau dengan jalan lelang, di pasar atau bursa dan cara lainnya yang lazim dilakukan sebagaimana yang dimaksudkan pada Pasal 1155 BW, melainkan cessionaris dapat langsung mengeksekusi piutang atas nama tersebut dari cessus.

\section{Konsep Hukum Cessie dan Pengajuan Gugatan di Pengadilan \\ 1. Pengaturan Umum}

Dalam sebuah konsep permasalahan baik yurisprudensi mauun doktrin, cessie dipahami sebagai peyerahan tagihan atas nama, biasa juga disebu pengalihan piutang. Pada konsep ini khususnya pada konsep tagihan atas nama terdapat ciri-ciri khas pada tagihan tersebut, yakni:

a. Bukan tagihan atas tunjuk;

b. Krediturnya dan debiturnya mengetahui betul siapa debiturnya;

c. Tagihan itu tidak ada wujudnya, dan

d. Surat utang berfungsi hanya sebagai alat bukti saja dan belum ada artian sebagai atau terjadinya pengalihan hak saja.

Dengan kata lain, cessie merupakan tagihan atas nama atau pengalihan piutang dalam bentuk kebendaan bergerak yang tak berwujud yang biasanya berupa piutang atas nama kepada pihak ketiga, yang mana seseorang yang menjual hak tagihnya kepada pihak lain atau orang lain. Cessie hanya dapat dilakukan dengan bentuk tertulis atau akta seseuai pada Pasal 613 KUHPerdata yang mewajibkan untuk membuat akta otentik ataupun akta di bawah tangan, pada akta pengalihan piutang cessie atau dapat disebut juga dengan akta cessie haruslah dinyatakan secara tegas mengenai tindakan cedent menyerahkan tagihan atas nama ke dalam kepemilikan cessionaris yang diikuti oleh tindakan penerimaan oleh cessionaris.

Tindakan penerimaan merupakan tindakan yang menyatakan menerima penyerahan cessie dari cedent, akibatnya jika cedent menyerahkan secara 
sepihak kepada cessionaris dan hanya memberitahukan kepada cessus, maka belum mengakibatkan adanya pengalihan atas tagihan dari cedent kepada cessionaris.

2. Pengalihan Atau Penyerahan Tagihan Atas Nama

Istilah dari cessie tidak ditemukan dalam KUHPerdata tetapi proses pengalihan ataupun penyerahannya telah diatur pada Pasal 613 ayat (1) KUHPerdata, dimana menyatakan:

"Penyerahan akan piutang-piutang atas nama dan kebendaan tidak bertubuh lainhya, dilakukan dengan jalan membuat sebuah akta otentik atau akta di bawah tangan dengan mana hak-hak atas kebendaan itu dilimpahkan kepada orang lain".

Pada Pasal 613 ayat (1) KUHPerdata di atas lebih kepada penegasannya akan adanya bentuk tagihan atas nama yang terkait dengan konsep mengenai benda yang tak bertubuh lainnya. Kemudia benda yang tak bertubuh lainnya adalah bukan dalam bentuk tagihan. Maka, penyerahan benda yang tak bertubuh yang bukan merupakan tagihan bukanlah merupakan cessie. Proses pengalihan dari tagihan atas nama dari pemilik kepada orang lain umumnya sama dengan proses peralihan kebendaan lainnya, seperti yang diatur Pasal 584 KUHPerdata, yang berbunyi:

"Hak Milik suatu kebendaan tidak dapat diperoleh dengan cara lain, melainkan dengan kepemilikan karena perlekatan, karena kedaluarsa karena pewarisan baik menurut undang-undang maupun menurut surat wasiat dank arena penunjukan atas penyerahan berdasarkan atas suatu peristiwa perdata untuk memindahkan hak milik dilakukan oleh seseorang yang berhak berbuat terhadap kebendaan itu".

Pemberitahuan atas adanya cessie, haruslah dalam bentuk tertulis atau berupa surat atau dokumen tertulis lainnya, tidak harus dalam bentuk atau melalui suatu putusan pengadilan, karena prinsipnya cessus mengetahui adanya cessie kepada cessionaris.

3. Pengajuan Gugatan Pengalihan Piutang dengan Skema Cessie Di Pengadilan Seperti yang kita ketahui pada pengajuan guagatn perdata pada umumnya dilakukan dengan dua cara yaitu dapat dilakukan pengajuan Gugatan Contentiosa atau biasa disebut dengan Gugatan Perdata dan juga dapat diajukan Gugatan Voluntair atau biasa dikenal di dunia peradilan dengan nama pengajuan permohonan. Lebih untuk memahami arti dari gugatan contensiosa dan gugatan voluntair, ada baiknya dibahas terlebih dahulu secara rinci agar lebih jelas dan dapat dipahami dari segi umumnya saja, sebagai berikut:

a) Gugatan Voluntair 
Gugatan voluntair biasa dikenal sebagai permohonan, sebutan ini dijelaskan Pasal 2 ayat (1) Undang-undang No. 14 Tahun 1970 (sebagaimana diubah dengan Undang-undang No. 35 Tahun 1999) yang menyatakan

"Penyelesaian setiap perkara yang diajukan kepada badan-badan peradilan mengandung pengertian di dalamnya penyelesaian masalah yang bersangkutan dengan yurisdiksi voluntair".

Adapun ciri khas gugatan voluntair atau permohonan menurut Yahya Harahap dalam bukunya, yaitu: ${ }^{16}$

1. Masalah yang diajukan bersifat sepihak semata (for the benefit of one party only);

2. Permasalahan yang dimohon penyesuaian kepada Pengadilan Negeri, yang pada prinsipnya tanpa sengketa dengan pihak lain (without disputes or differences with another party);

3. Tidak ada orang lain atau pihak ketiga yang ditarik sebagai lawab, tetapi bersifat ex-parte.

b) Gugatan Contentiosa

Gugatan contentiosa biasa dekenal sebagai gugatan perdata, telah dijelaskan pada Pasal 2 ayat (1) Undang-undang No. 14 Tahun 1970 (sebagaimana diubah dengan Undang-undang No. 35 Tahun 1999), dan sekarang dalam Pasal 16 ayat (1) Undang-undang No. 4 Tahun 2004 sebagaimana pengganti Undang-undang No. 14 Tahun 1970. Selanjutnya hal itu dalam Undang-undang No. 48 Tahun 2009 sebagaimana pengganti Undang-undang No. 4 Tahun 2004 ditur dalam Pasal 25 ayat (2). Wewenang pengadilan menyelesaikan perkara diantara pihak yang bersengketa, disebut yurisdiksi contentiosa dan gugatannya berbentuk gugatan contentiosa, merupakn hal yang berbeda atau berlawanan dengan yurisdiksi gugatan voluntair yang bersifat sepihak (ex-parte).

Gugatan contentiosa disini merupakan gugatan yang mengandung sengketa di antara kedua belah pihak atau lebih. Permasalahan yang diajukan dan di minta untuk diselesaikan dalam gugatan, merupakan sengketa atau perselisihan di antara para pihak (between contending parties). ${ }^{17}$

Dengan pengertian dari gugatan contentiosa dan gugatan voluntair di atas maka dalam halnya dengan pengalihan piutang atau pengalihan hak

16 M. Yahya Harahap, Hukum Acara Perdata (gugatan, persidangan, penyitaan, pembuktian dan putusan pengadilan), edisi kedua, (Jakarta: Sinar Grafika,2019). h. 30.

${ }^{17}$ Ibid, h. 48. 
atas nama dengan skema cessie pada dasarnya melalui gugatan contentiosa, tetapi setalah menelititi di lapangan khususnya di pengadilan agama pengajuan pengalihan piutang dengan skema cessie juga bias dilakukan pengajuan gugatan voluntair atau mengajukan permohonan, sebab pada perkara cessie yang telah diketahui bahwasanya debitur baru akan menanggung piutang dari debitur lama dengan jalur membeli jaminan dari pihak bank yang telah menarik jaminan yang diberikan kepada debitur lama dahulu tidak perlu lagi diajukan gugatan contentiosa sebab tidak adanya sengket di dalamnya melainkan hanya bentuk permohonan balik nama sertifikat dari obyek yang telah dijaminkan khususnya obyek tanah ataupun bangunan.

Kemungkinan juga yang sering terjadi kurangnya perkara pengalihan piutang dengan skema cessie ini yang masuk di pengadilan sehingga pegawai pengadilan, panitera, maupun hakim belum memahami perkara cessie ini, sehingga yang terjadi yaitu pengulangan atau perbaikan gugatan yang diajukan Advokat dalam mewakili pemberi kuasa dalam registrasi atau pendaftaran perkara cessie ini di pengadilan serta segala proses peradilan yang di jalani.

Karena kemungkinan kurangnya perkara cessie ini masuk ke pengadilan maka dapat mengakibatkan kerugian materil dari seorang atau lebih pemberi kuasa, itu mungkin kekurangan yang timbul. Lalu kemudian, kelebihan yang terjadi yaitu, para penegak hukum khususnya dalam hukum keperdataan dalam bidang perkara pengalihan piutang cessie, akan menambah pengetahuan atau wawasan untuk para advokat dan khususnya untuk para panitera serta hakim yang menangani perkara ini serta dapat menganalisa apa yang diinginkan dari gugatan yang diajukan oleh advokat di pengadilan.

Kemudian dalam pengalihan piutang dengan skema cessie ini dapat melalui gugatan contentiosa maupun gugatan voluntair, dan juga pengajuannya juga dapat diajukan di pengadilan agama maupun pengadilan negeri. Jika perkara cessie tersebut berada pada pihak perbankan syariah maka perkara itu dapat di daftarkan pada pengadilan agama sesuai dengan kompetensinya masing-masing sesuai dengan ketentuan perundang-undangan dalam kaitannya dengan kompetensi mengadili maupun kompetensi lainnya. Kemudian, jika perkara cessie tersebut berada pada pihak perbankan umum atau dengan kata lain bank konvensional, maka gugatan dapat diajukan ke pengadilan negeri sesuai dengan kompetensinya masing-masing. 
Dalam bentuk gugatan yang diajukan juga bias menggunakan gugatan voluntair maupun gugatan contentiosa. Jika ada sengketa pada perkara cessie tersebut seperti tidak maunya debitur lama untuk mengosongkan kediaman yang akan dibeli oleh debitu baru maka dapat dimintakan kepada hakim dalam petitum gugatan untuk mengosongkan rumah tersebut dalam keadaan benar-benar kosong di pengadilan. Namun jika perkara pengalihan piutang dengan skema cessie tersebut tidak mengandung sengketa maka dapat diajukan gugatan voluntair atau mengajukan sebuah permohonan ke pengadilan sesuai dengan kompetensinya baik kompetensi absolut maupun kompetensi relatifnya harus disesuaikan agar tidak menyalahi perundang-undangan atau peraturan yang berlaku.

\section{PENUTUP}

\section{A. Kesimpulan}

Berdasarkan pembahasan diatas maka, disimpulkan sebagai berikut :

1) Secara umum bahwa pengalihan piutang secara cessie tidak terdapat dalam perundangan, tetapi kata Cessie tidak terdapat di dalam undang-undang yang telah berlaku di Indonesia. Pasal 613 KUHPerdata atau BW berada dalam bagian Kedua Buku II BW di bawah judul "Tentang Cara Memperoleh Hak Milik", namun pada pengertiannya cessie adalah sebuah cara untuk mengalihakan piutang atas nama tanpa mengakibatkan perjanjian kredit atau pinjaman atau pinjam meminjam uang yang akan berakibat munculnya piutang menjadi terhapus.

2) Dalam pengalihan piutang dengan skema cessie ini dapat melalui gugatan contentiosa maupun gugatan voluntair, dan juga pengajuannya juga dapat diajukan di pengadilan agama maupun pengadilan negeri. Jika perkara cessie tersebut berada pada pihak perbankan syariah maka perkara itu dapat di daftarkan pada pengadilan agama sesuai dengan kompetensinya masingmasing sesuai dengan ketentuan perundang-undangan dalam kaitannya dengan kompetensi mengadili maupun kompetensi lainnya. Kemudian, jika perkara cessie tersebut berada pada pihak perbankan umum atau dengan kata lain bank konvensional, maka gugatan dapat diajukan ke pengadilan negeri sesuai dengan kompetensinya masing-masing, baik kompetensi absolutnya maupun kompetensi relatifnya perlu diperhatikan.

B. Saran

1) Permasalahan yang berkaitan dengan pengalihan piutang dengan skema cessie khususnya di dunia peradilan perlu disebar luaskan pemahamannya 
sebab masih kurangnya pemahaman tentang cessie itu sendiri, yang paling penting adalah kompetensi absolut dan kompetensi relatifnya yang kemudian harus di perjelas dan diperhatikan. Karena akan berdampak pada kerugian materil terhadap penggungat ataupun pemohon. 


\section{DAFTAR PUSTAKA}

\section{Buku}

Budiono, Herlien. Ajaran Umum Hukum Perjanjian dan Penerapan di Bidang Kenotariatan. Bandung: Citra Aditya, 2010.

H.S, Salim. Pengantar Hukum Perdata Tertulis (BW). Jakarta: Sinar Grafika, 2005.

Harahap, M. Yahya. Hukum Acara Perdata (gugatan, persidangan, penyitaan, pembuktian dan putusan pengadilan), edisi kedua. Jakarta: Sinar Grafika, 2019.

Hermansyah, Hukum Perbankan Nasional Indonesia, Edisi 2, Cet.8. Jakarta: Prenada Media Group, 2014.

Irmayanto, Juli dkk. Bank dan Lembaga Keuangan. Jakarta: Universitas Trisakti, 2004.

Marzuki, Peter Mahmud. Penulisan Hukum. Jakarta: Kencana Prenada Media Group, 2014.

Satrio. Cessie, Subrogatie, Novatie, Kompensatie dan Percampuran Hutang, Cet. 2. Bandung; Alumni, 1999.

Setiawan, Rahman dan J. Satrio. Penjelasan Hukum tentang Cessie. Jakarta: PT. Gramedia, 2010.

Soeharnoko dan Endah Hartati. Doktrin Subrogasi, Novasi dan Cessie. Jakarta: Kencana, 2008.

Subekti. Pokok-Pokok Hukum Perdata, Cet. 31. Jakarta: Intermasa, 2003.

Suharnoko. Doktrin Subrogasi, Novasi, dan Cessie, edisi pertama. Jakarta: Kencana Prenada Media Group, 2003.

Usman, Rachmadi. Hukum Jaminan Keperdataan. Jakarta: Sinar Grafika, 2009.

\section{Peraturan Perundang-Undangan:}

Undang-Undang RI Nomor 4 Tahun 1996 Tentang Hak Tanggungan 